\title{
Mechanisms of sperm-egg interactions emerging from gene-manipulated animals
}

\author{
MASAHITO IKAWA, NAOKAZU INOUE and MASARU OKABE* \\ Research Institute for Microbial Diseases, Osaka University, Suita, Osaka, Japan
}

\begin{abstract}
Sperm-egg interactions have been studied for many years using biochemical approaches such as the employment of antibodies and ligands that interact with sperm or with eggs and their vestments. As a result, various factors that participate in fertilization have emerged. However, when animals were genetically manipulated to examine the roles of those factors, most of them were found, to our surprise, to be "not essential". Of course, all biological systems contain redundancies and compensatory mechanisms, but at least some factors were found to be "essential" after gene disruption. As a whole, the explanations of sperm-egg interactions require significant modification from the gene manipulation point of view. In this review, information about sperm-egg interactions obtained from genetically manipulated animals is mainly revisited in order to propose a new vision.
\end{abstract}

KEY WORDS: fertilization, knockout mouse, sperm-zona interaction, sperm-egg fusion

\section{Introduction}

About a billion years ago, living organisms devised sex (Margulis and Sagan, 1986) to facilitate a genetic shuffling for better survival and quick evolution. Since then enormous numbers of recognition and fusion of males and females have been successfully accomplished and the process has evolved immensely. In mammals, males produce innumerable tiny sperm while females produce much larger eggs with a thin glycoprotein layer: the zona pellucida. How do sperm and egg recognize each other, make contact, and achieve fusion? Various factors have been reported with convincing evidence. However, the recently-introduced, homologous gene disruption technique revealed many of the genes were dispensable because the animals devoid of those genes showed substantial fertilizing ability. One can argue that the disappearance of a factor could be compensated by adjusting the amount of equally functioning factors in gene disruption experiments. However, sperm are like "rockets" with limited resources available once launched. Sperm DNA are tightly packed with protamine and the transcriptions are shut down. Even if the sperm can carry out some de novo protein synthesis during capacitation using stored mRNA and mitochondrial ribosomes (Gur and Breitbart, 2006), it is difficult to imagine that the sperm rearrange their function by replacing one factor with others. One can also argue that, based on the importance of fertilization phenomena, various steps are made with backup systems. However, recent gene disruption experiments indicated that there are "essential" factors in fertilization, because in various cases, the lack of a factor leads to the complete loss of fertilizing ability of gametes. Thus the quest for more "essential" factors and analysis of the relationship among those factors represent the most promising path to elucidate the mechanism of fertilization in molecular bases. In the present review, we introduce essential factors in fertilization and clarify their relationships.

\section{Eggs}

Eggs are released into the peritoneal or bursal cavity and then are picked up by the cilia of the infundibulum. Mammalian eggs are almost invariably covered by numerous cumulus cells and an extensive extracellular matrix, which is recognized by specific receptors on the tips of the cilia. Pickup of this complex by the oviduct has been recorded in beautiful video pictures available online by Talbot et al. using hamsters (Talbot et al., 1999) (Fig. 1).

After being picked up from the infundibulum, the eggs move to the ampulla of the oviduct and wait to be fertilized by sperm. It is not clear why or how they stay in this area, but they do, enveloped in the cumulus mass until fertilization occurs. Eggs have fertilizing ability depending on the nature of cumulus cells and zona pellucida (Yanagimachi, 1994), but surprisingly, fus-

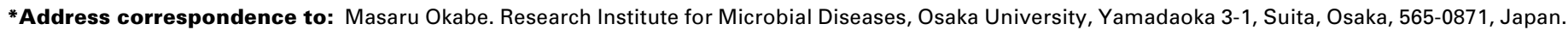
Tel: +81-6-6879-8375. Fax: +81-6-6879-8376. e-mail: okabe@gen-info.osaka-u.ac.jp Web: http://kumikae01.gen-info.osaka-u.ac.jp/EGR/index.cfm
} 


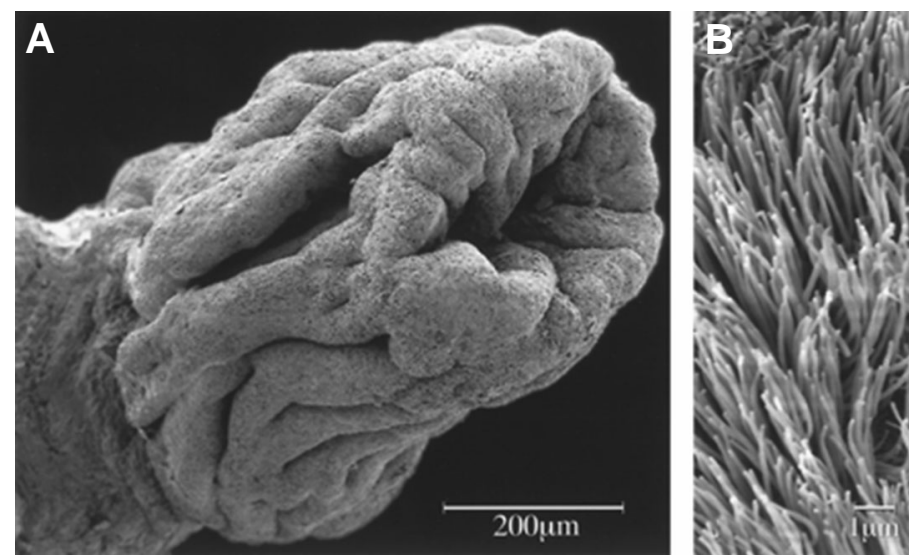

Fig. 1. Hamster infundibulum and magnified view of cilia on its surface (Talbot et al., 1999). An online video showing the movement of ovulated eggs into the oviduct is available at: http://www. molbiolcell.org/ content/vol10/issue1/images/video/mk0190776002b.mov

ing ability with sperm is formed even as - the immature eggs develop without cumulus cells inside mouse testis (Isotani et al., 2005).

\section{Sperm}

Sperm and eggs move in different directions. Sperm need to ascend the female reproductive tract to find eggs residing in the oviduct, while the eggs descend the oviduct and enter the uterus after fertilization. Usually one egg in humans and about ten in mice await sperm in the oviduct. Compared to the numbers of eggs, an overwhelming number of sperm are ejaculated into the female reproductive tract. However, only a small number of sperm reach the fertilization site. The uterus and oviduct are connected at the uterotubal junction (UTJ). The outer portion of the oviduct hangs into the uterus and forms a colliculus in mice, pigs and cows. The tract is very narrow at the UTJ and sperm are not able to migrate freely into the oviduct through the UTJ, decreasing the number of sperm participating in fertilization. It is not known if only selected sperm can penetrate the UTJ, but various factors are known to be essential for sperm to pass through the UTJ (Cho et al., 1998, Hagaman et al., 1998, Ikawa et al., 2001, Nishimura et al., 2004). When we made chimeric mice that ejaculated a mixture of wild-type sperm and motile but not fertile sperm from calmegindisrupted mice, only the former sperm in the same ejaculates could migrate to the oviduct. This result indicates a possibility of selection at the UTJ (Nakanishi et al., 2004).

Sperm chemotaxis toward eggs before fertilization has been demonstrated clearly in ascidians (Yoshida et al., 2002). In humans, olfactory receptors (ORs) on sperm might function in finding eggs. The hOR17-4 was demonstrated to function in human sperm chemotaxis (Spehr et al., 2003). Mouse sperm might also locate eggs by sensing a chemoattractant (Fukuda et al., 2004). The disruption of an ion channel expressed in VNO neurons are reported to cause females to behave like males (Kimchi et al., 2007). The contribution of ORs in fertilization must be proven by gene disruption experiments.

Sperm are produced in the testis, transferred into the epididymis and remain stored in the cauda epididymis. Once ejaculated, they must be activated by stimuli from the female environment and start to swim vigorously. Only capacitated and acrosomereacted sperm are competent to fertilize eggs, like matches being struck and activated before acquiring capability to cause fire (Fig. 2)

The nature of the capacitation process is not well understood, but there are many papers indicating the importance of protein phosphorylation and calcium ion influx upon release of "decapacitation factor(s)" from sperm (De Jonge, 2005). It should be noted that the acrosome reaction is a change that happens only in capacitated spermatozoa and gradually increases to 30$40 \%$ during $1-2 \mathrm{~h}$ of incubation in vitroin mouse sperm population. This means sperm are not homogeneous but are individually different from each other. However, most reports treat sperm as a mixed mass to evaluate sperm status because there is not a convenient method to separate sperm at different stages of capacitation and/or acrosome reaction. We must be aware that this homogeneity problem exists in the experiments which analyze sperm as a combined mass.

Various methods are proposed to observe acrosome reaction (Cross and Meizel, 1989, Larson and Miller, 1999, Saling and Storey, 1979). Our strategy to observe the acrosomal status under microscope is to use transgenic mouse lines with green fluorescent protein (GFP) in their acrosome. We produced transgenic mice whose sperm have GFP in their acrosome; the green fluorescence is clearly seen with no previous treatment of sperm. After the acrosome reaction, GFP disappears within three seconds (Nakanishi et al., 1999). Sperm from these mice could easily be analyzed using a flow cytometer, and real-time analysis of acrosome reaction is possible (Nakanishi et al., 1999). Although the GFP disperses from acrosome rapidly, other acrosomal components such as MN7 antigen and MC41 antigen remain on sperm for at least $15 \mathrm{~min}$. Thus, it was shown that the acrosome reaction is not a simple all-or-none phenomenon, but one with intermediate stages. Sperm-egg interactions must be investigated taking into account factors such as an intermediate stage of acrosome-reacted sperm (Kim and Gerton, 2003).

The acrosin-GFP mice are available to the public through RIKEN BRC or CARD, Kumamoto University under the registered name, B6;C3 Tg(acro3-EGFP)01Osb or C57BL/6-Tg(CAG/AcrEGFP)C3-N01-FJ002Osb (http://www.brc.riken.jp/lab/animal/en).

\section{Sperm-egg interactions: an original view}

$\mathrm{PH}-20$ has been indicated to have a role in sperm binding with the zona pellucida, based on the finding that two out of the three monoclonal antibodies raised against $\mathrm{PH}-20$ inhibited spermzona binding (Primakoff et al., 1988). In 1993, a group studying snake venom found a significant homology of hyaluronidase to $\mathrm{PH}-20$ (Gmachl and Kreil, 1993). These structural data seemed to support the long-held view that hyaluronidase plays a role in fertilization. In fact, in macaque monkeys, zona penetration was completely blocked by anti-PH-20 lgG when present during sperm-oocyte interaction (Yudin et al., 1999). However, when $\mathrm{PH}-20$ gene-disrupted mice were produced and examined, the mice showed a reduced ability to disperse cumulus cells but were found to be fertile (Baba et al., 2002). Baba's group found a remaining hyaluronidase activity in $\mathrm{PH}-20$ disrupted mouse sperm, and they discovered an additional sperm specific hyaluronidase 
gene Hyal5 very close to $\mathrm{PH}-20$ in the genome (Kim et al., 2005). The role of hyaluronidase in sperm-egg interaction will be concluded when we see the binding ability impaired sperm from Hyal5 knockout or $\mathrm{PH}-20$ and Hyal5 double knockout mice.

There are more factors suggested to be involved in spermzona interactions. Beta 1,4-galactosyltransferase (GalTase) is reported to function not as an enzyme, but as a sperm-eggbinding factor. Various reports exist supporting this notion. However, when a GalTase-disrupted mouse line was produced by Shur's group, unexpectedly it was found that sperm lacking GalTase could fertilize eggs and the males were not sterile although there were some minor defects in sperm-egg interactions (Asano et al., 1997, Lu and Shur, 1997). This could be interpreted as suggesting that the role of GalTase was compensated by other factors and another candidate SED1 was reported as a second zona-binding factor (Ensslin and Shur, 2003). When SED1 gene was disrupted, it was found that the mice were not sterile. Such an unexpected outcome by disrupting genes for sperm-egg interaction dates back to 1994. The first gene disruption aimed at studying sperm-egg interaction was the gene for acrosin. Despite hundreds of papers supporting the importance of sperm acrosin in fertilization, acrosin-null sperm can still fertilize eggs, albeit with a slight delay compared with wild type (Adham et al., 1997, Baba et al., 1994). Baba's group found that protease activity persists in the sperm of acrosin gene-disrupted mouse. Altogether they found five more testis-specific proteases, from TESP1 to TESP5 (Honda et al., 2002), but the roles of these enzymes in fertilization await further investigation.

There are further examples that the disruption of "important" factors results in an unexpectedly mild phenotype or shows an unpredicted phenotype in fertilization. Fertilin was originally clarified as an antigen recognized by the anti-guinea pig sperm monoclonal antibody $\mathrm{PH}-30$. As the $\mathrm{PH}-30$ antibody inhibited sperm from fusing with eggs, the $\mathrm{PH}-30$ gene was cloned and analyzed. The antigen was found to be a heterodimer and one of the monomer genes contains a fusogenic domain similar to viral fusogen. Moreover, the other half of the heterodimer was found to contain a disintegrin domain, which binds to integrin. Thus the antigen that reacts to $\mathrm{PH}-30$ was speculated to be a fusion protein and named "fertilin," which consists of fertilin alpha and beta (ADAM1/2) heterodimer(Blobel et al., 1992). After this report, various types of circumstantial evidence were reported to support the role of fertilin. However, when Adam2, which forms a fertilin heterodimer, disrupted mice were produced, they found that Adam2-null sperm was shown to have fusing ability with eggs but unexpectedly, the sperm failed to bind to zona pellucida (Cho et al., 1998). Later, it was found that Adam1 consisted of two independent genes: Adam1a and Adam1b (Nishimura et al., 2002). Both of the ADAM1 family proteins could make a heterodimer with ADAM2, but "fertilin" on sperm surface was found to be exclusively an ADAM1b/ADAM2 type. Baba's group disrupted the ADAM1b gene but the mice were fertile without fertilin on sperm (Kim et al., 2006).(This will be discussed below.) Similar stories continue in disruptions of CD46 (Inoue et al., 2003), ZPBP1 (Lin et al., 2007) and PKD-REJ (our unpublished data) and in some more factors (private communications).

If the fertilization mechanism consists of-redundantly prepared factors, it is not possible to analyze the role of factors with a single gene disruption experiment. If this was the case, the above mentioned factors may represent the redundant factors. If there is a factor which is not redundant and not able to be compensated, the disruption of a concerned factor must produce sterile mice. Such cases are described below.

\section{Sperm-egg interactions: an emerging view}

The first case of normally swimming sperm with normal shape and numbers failing to fertilize eggs was our report on the calmegin gene-disrupted mouse (lkawa et al., 1997). Calmegin ${ }^{-}$ - males are almost sterile with a lack of sperm zona-binding ability. When sperm from such males were added to cumulus-free eggs and observed under the microscope, we noted that the sperm had lost their zona-binding ability and were bouncing off the zona pellucida. However the calmegin is not directly involved

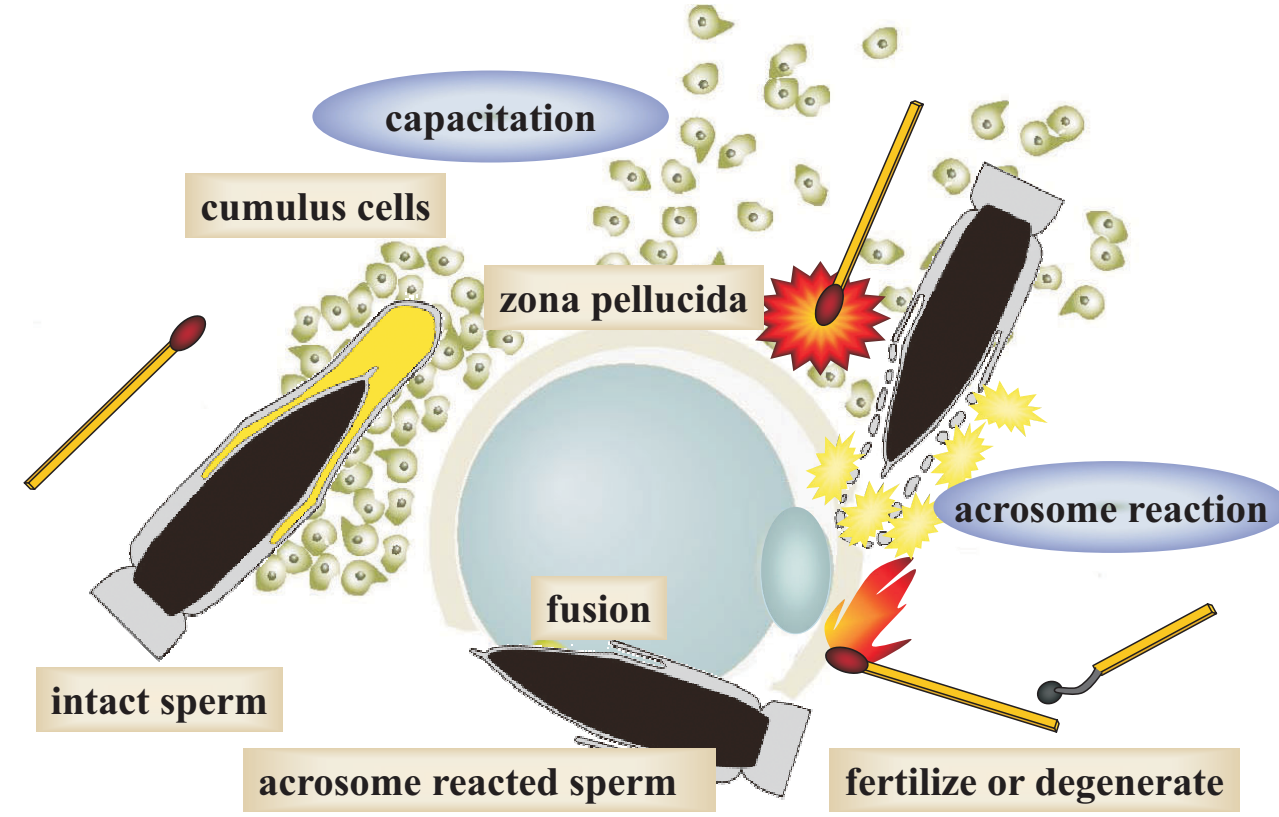

Fig. 2. Mechanism of sperm-egg interaction. Sperm stored in the epididymis are kept metabolically inert to facilitate prolonged storage (left). Each sperm has a membranous sac over the nucleus called the acrosome which is filled with many kinds of hydrolytic enzymes. After sperm are exposed to the female reproductive environment, they become metabolically active. They undergo capacitation, which permits the acrosome reaction, and start to swim extremely vigorously (hyperactivation). Near the eggs, probably stimulated by the cumulus cells and zona pellucida, they undergo the acrosome reaction to release the acrosomal contents by exocytosis. Only acrosomereacted sperm are known to fuse with eggs but their competency for fusion does not last long. The integrity of the acrosome in the mouse sperm can be monitored easily by using transgenic mice in which the GFP protein is targeted to the acrosomal contents (Nakanishi et al., 1999). 
in sperm-egg interactions. Calmegin is a testis-specific homologue of the ubiquitously-expressed endoplasmic (ER) molecular chaperone calnexin. During spermatogenesis, sperm shed machineries for protein synthesis, including the ER. Thus, even in wild-type mice, there is no calmegin left on the sperm. Therefore, it is easily speculated that calmegin is acting to fold molecule(s) that are destined to function in sperm-egg binding. After we published the calmegin disruption, two other gene disruptions, Adam2 and angiotensin converting enzyme (ACE), were found to result in male sterility. Peculiarly, these knockout mouse lines and calmegin knockout mice share the phenotype of impaired zonabinding ability and, at the same time, an impaired UTJ penetrating ability. We thought the interaction of calmegin with ADAM2 was conceivable, so we immunoprecipitated calmegin from testicular lysate and examined the interaction of calmegin with ADAM2. Immunoprecipitation followed by western blot analysis revealed that ADAM1a, ADAM1b and ADAM2 formed complexes specifically with calmegin in the ER. The disruption of calmegin was shown to cause impaired heterodimerization of ADAM1a/2 and ADAM1b/2 leading to the complete loss of ADAM2 from mature sperm. Thus the reason why the calmegin and Adam2-disrupted mice share the same phenotypes became clear (lkawa et al., 2001).

To our surprise, the Adam3-disrupted male mice were also sterile with impaired zona-binding ability (Shamsadin etal., 1999). Why did so many gene disruptions result in a single phenotype? This was explained by a simple reason. The amount of an ADAM family protein in sperm is easily affected by the disappearance of other ADAM family members. Baba's group found the testis specific ADAM1a was essential in fertilization, but they also found that when ADAM1a was eliminated, ADAM3 also disappeared from sperm, (Nishimura et al., 2004). The synchronized disappearance of ADAM family proteins are reported by many researchers (Cho et al., 1998, Ikawa et al., 2001, Nishimura et al., 2004, Stein etal., 2005). A stunning result was reported by Baba's group. When they produced Adam1b (fertilin beta) disrupted mice, they found Adam2 also disappeared from sperm, but the sperm were fertile (Kim et al., 2006). This result clearly indicates that the intensively studied protein "fertilin" is dispensable in fertilization. Combining these data together, ADAM3 emerged to be a putative key molecule in fertilization. The mechanism of infertility caused by ACE disruption remained unclear for many years. However, the relationship between ACE and ADAM3 was demonstrated. When we analyzed the ADAM3 in Ace-disrupted mice, we suggested the membrane micro-domain specific disappearance of ADAM3. We found a significant decrease of ADAM3 on Ace-/- sperm in the Triton X-114 detergent-enriched phase after phase separation, while ADAM2 remain unchanged on sperm (Yamaguchi et al., 2006) (Fig. 3).

Combining these facts together, the most important factor that may participate in sperm-zona binding is tentatively ADAM3 (Yamaguchi et al., 2006). However, multiple isoforms of Adam3 transcripts observed in the human were non-functional owing to the presence of deletions and in-frame termination codons (Frayne et al., 1999). Therefore, ADAM3 cannot be an ultimate universal zona-binding factor among mammals.

In terms of other candidate factors for zona binding, sp56 was identified as having the characteristics expected of the sperm protein responsible for recognition of egg zona pellucida. The complementary DNA encoding sp56 was isolated and its primary sequence indicates that sp56 is a member of a superfamily of protein receptors (Bookbinder et al., 1995). Zonadhesin is a multiple-domain transmembrane protein believed to function as a sperm-zona pellucida binding protein(Hardy and Garbers, 1995, Jansen etal., 2001, Lea etal., 2001, Wassarman, 1992). We must examine the fertilizing ability of sperm that lack these factors to reach a definite conclusion.

Moreover, it should be noted that all of the calmegin, ADAM1a, ADAM2- and ACE-disrupted mouse sperm share the phenotype of inability, not only to bind to zona, but also to migrate into the oviduct. (Cho et al., 1998, Hagaman et al., 1998, Ikawa et al., 2001, Nishimura et al., 2004) The puzzle is why the two different inabilities of sperm-zona binding and oviduct migration run in parallel in these gene disruption experiments. We believe this phenomenon could be a good clue in helping to understand the molecular mechanisms of fertilization.

\section{Membrane fusion}

The lipid membrane has fluidity both horizontally and transversely and here are various mechanisms to maintain the lipid constitutions of both the outer and inner sides of the membrane. When the cell needs to divide, the membrane must be separated into two sections. Topologically, to achieve this, there must be a membrane break in the lipid bilayer at some point of the cytokinesis. If the egg membrane is broken artificially, as when we make a hole in the egg membrane to do intracytoplasmic sperm injection (ICSI), the opening normally seals back immediately. However, the ability for restoration is not consistent. It differs depending on the stage of the eggs. It also differs depending on the species. For example, mouse eggs are much more fragile than human eggs. We are not aware of the causes, but the adjustment and formation of a characteristic nature of the membrane must occur through a combination of various mechanisms such as the membrane undercoat and the constitution of lipids to form membrane. Sperm membrane is also known to have a complicated structure that contains cholesterol-dense "rafts" which are modified extensively during sperm capacitation (De Jonge, 2005), and evenly observed membrane by electron microscope is actually divided in some areas when examined by anti-sperm antibody.

Various important membrane fusion events exist in several tissues. For example, skeletal muscle cells are formed after myoblast cell fusion. Trophoblast cells fuse with each other to form syncytiotrophoblasts, which are necessary for implantation. Osteoclasts resorb the bone at multiple sites, occasionally containing more than 100 nuclei, and are formed by cell fusion(Yagi et al., 2005). Mitochondrial membranes are known to fuse with neighboring mitochondrial membranes using mitofusin1 and mitofusion2 (Chen and Chan, 2005). One of the most precisely investigated fusion processes is exocytosis. SNAREs (soluble $N$ ethylmaleimide-sensitive fusion protein attachment protein receptors) and some kinds of viruses appear to mimic the fusion mechanism using SNAREs for invasion. (Chan et al., 1997, Lu et al., 1995, Weissenhorn et al., 1997). The structures of viral fusion proteins suggest that the fusion machineries employ a fundamentally similar mechanism to coalesce lipid bilayers. Fertilization is the phenomenon that involves membrane fusion between the plasma membrane of an unfertilized egg and the freshly-rear- 
ranged sperm membrane soon after the acrosome reaction. Both gametes have to be conditioned properly to accomplish membrane fusion, but the factors involved in fusion were not known for many years.

\section{Sperm-egg fusion in gene disrupted mice}

Gene disruption experiments not only destroy the predicted importance of various factors, but also introduce new factors in the mechanism of fertilization. Because all who produce gene knockout mouse lines need to breed them to keep the strain alive, if there is any defect in the fertilization process, it will inevitably draw the attention of researchers in any field. For example, CD9 was disrupted aiming to determine the effects on immune functions. However, the CD9-deficient mice looked healthy and lived normally, but surprisingly, the females lacking CD9 were sterile,

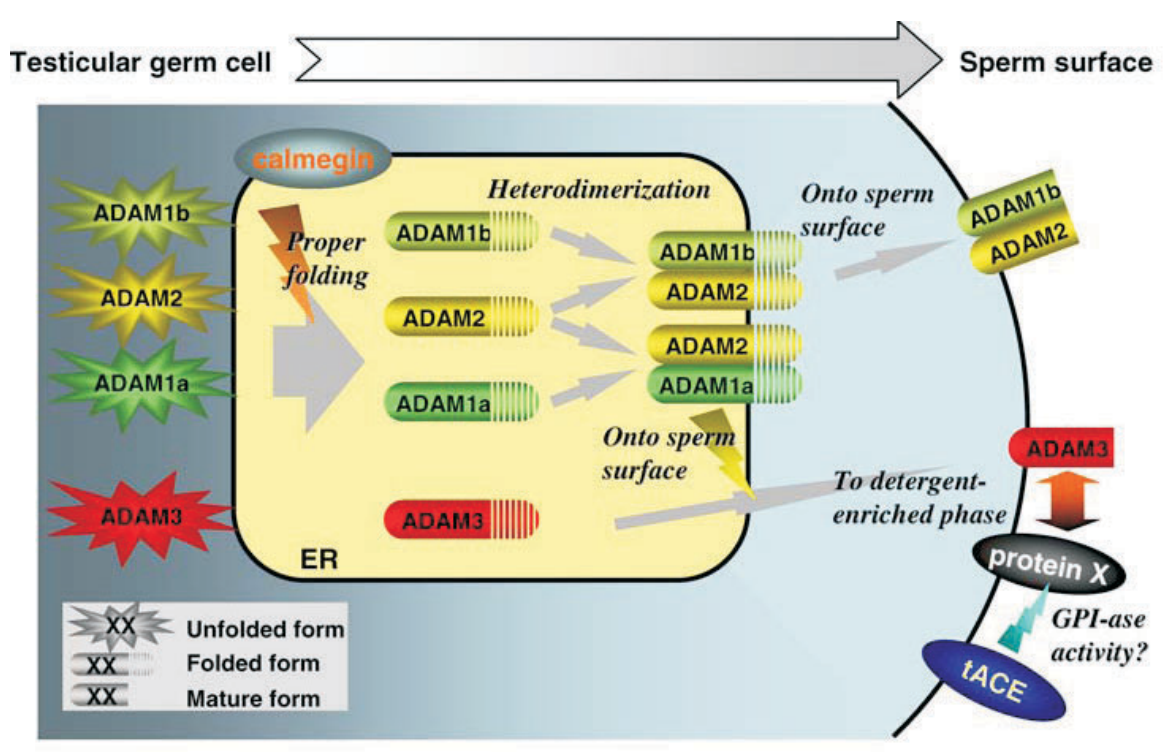

(a) Clgn-KO

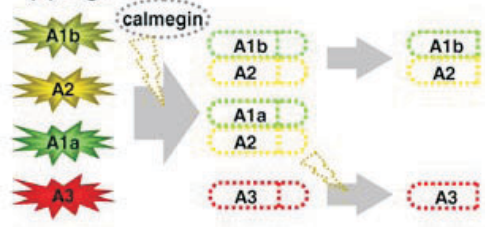

(b) Adam2-KO

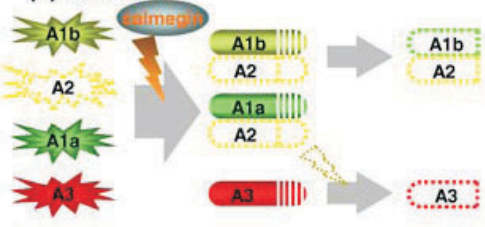

(c) Adam1a-KO

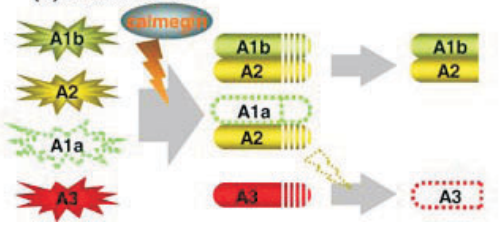

while the male mice remain normal (Kaji et al., 2000, Le Naour et al., 2000, Miyado et al., 2000). We analyzed the cause of the sterility using in vitrofertilization (IVF) and found that the eggs had no fusing ability with sperm (Miyado et al., 2000). Since fusion did not take place, the cortical granules were not released to block the polyspermy (Barros and Yanagimachi, 1971, Yanagimachi, 1994) which allowed multiple sperm to penetrate into the perivitelline space as shown in Fig. 4A. Thus, the very first discovery of an essential factor in sperm-egg fusion was found serendipitously.

CD9 is a member of the "tetraspanin" family of proteins having four transmembrane domains and ability to bind with integrins. Since integrins $\alpha 6$ and $\beta 1$ were found on the egg membrane, the effect of the addition of synthetic integrin peptides in the IVF system was examined and the inhibition of sperm-egg fusion was reported (Chen et al., 1999). However, again the gene disruption experiments in integrin $\alpha 6$ and $\beta 1$ revealed that both integrins are not essential for eggs to fuse with sperm (Miller et al., 2000).

Sperm must have completed the acrosome reaction prior to fertilization. This may imply that fusogenic factors are latent in fresh sperm and exposed only after acrosome reaction. We raised monoclonal antibodies against human sperm and screened one which did not react to fresh sperm, but to acrosome- reacted sperm. If the antibody could inhibit sperm-egg fusion, the corresponding antigen could be a good candidate as a fusion factor. Based on this hypothesis, we raised the anti-human sperm monoclonal antibody $\mathrm{MH} 61$ to meet

Fig. 3. Schematic model for ADAMs and their roles in sperm function. The disruption of the genes that encode Adam1a, Adam2, and Adam3 results in impaired sperm-ZP binding. CLGN is required for the folding of ADAM1a, ADAM1b, and ADAM2 and the subsequent dimerization of these proteins. In Clgn-/- (a) and Adam2-/- (b) sperm, the disappearance of the ADAM1al ADAM2 and ADAM1b/ADAM2 heterodimers results in the loss of ADAM1b, ADAM2, and ADAM3 from the sperm. ADAM1a is a testis-specific protein that is not found in sperm (Kim et al., 2003). When ADAM1a is eliminated (c), the ADAM1a/ADAM2 heterodimer disappears from the testis, whereas the expression of ADAM1b/ ADAM2 is not affected. However, these sperm lack ADAM3 (Nishimura et al., 2004). The disruption of $A D A M 3(\mathbf{d})$ is reported to have no significant effect on ADAM1a, ADAM1b or ADAM2 (Nishimura et al., 2001). These findings suggest that ADAM3 is located downstream of these other ADAM proteins. The disruption of tACE leads to the aberrant localization of ADAM3 (e), most likely due to a different pathway from the one hypothesized for CLGN/ADAMs. These results indicate the importance of ADAM3 in sperm$Z P$ interaction and explain why disruption of the individualAce, Clgn, Adam1a, Adam2, and Adam3 genes produces similar phenotypes. 


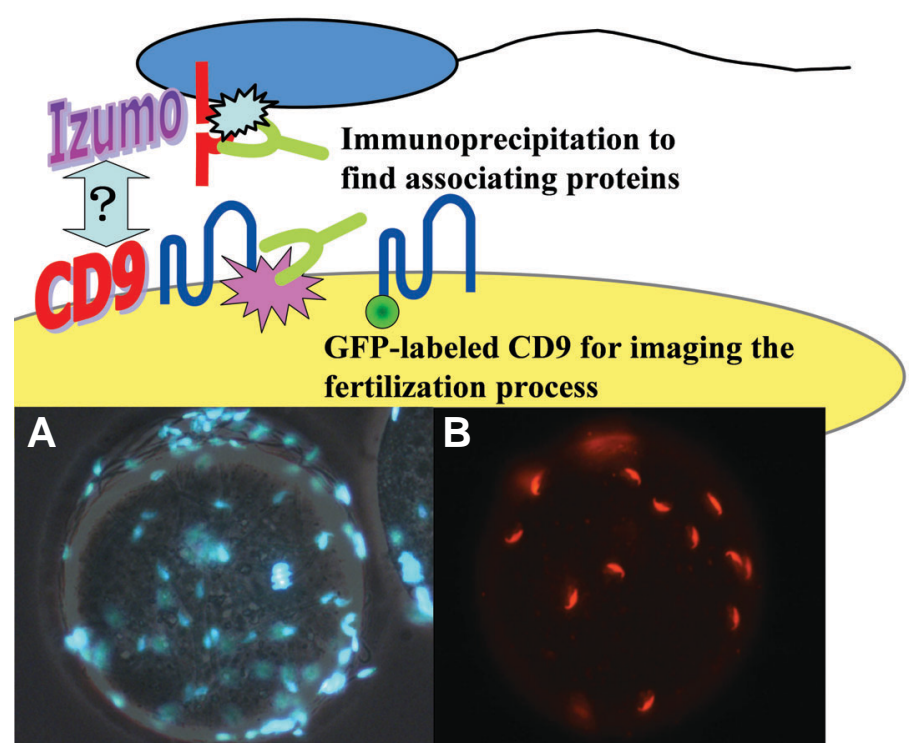

Fig. 4. Accumulation of sperm in the perivitelline space caused by failure of sperm-egg fusion. Only one factor each on sperm and eggs is available at the moment. As in the case of live imaging acrosome reaction (ftp://ftp.gen-info.osaka-u.ac.jp/ARmovie/), the imaging of the fusion factors at the time of fertilization may be possible by producing fluorescent chimeric proteins. Immunoprecipitation will also clarify the new factors involved in the fusion event. (A) Sperm accumulated in the perivitelline space of CD9-/-mouse eggs. The sperm could penetrate the zona pellucida but failed to fuse with the egg surface. Many sperm were able to enter because of the lack of egg activation, which normally leads to cortical granule release and the zona block to polyspermy. Sperm nuclei were stained with Hoechst 33342(Miyado et al., 2000). (B) Similarly, when eggs were inseminated with Izumo-/- sperm, the sperm could penetrate the zona pellucida but failed to fuse with the eggs. This also resulted in the accumulation of many sperm inside the perivitelline space (Inoue et al., 2005). These penetrated sperm had clearly undergone the acrosome reaction, as they were all exposing the acrosome reacted sperm-specific antigen MN9 (Toshimori et al., 1998).

this criterion (Okabe et al., 1990). The reacting antigen was identified as CD46, whose function is reported to be a complement receptor in human. However, when we cloned the CD46 gene in mouse, CD46 was found to be present only on sperm (Tsujimura et al., 1998). We thought that this suggested the original role of CD46 was to function in sperm-egg interaction. Therefore, we produced CD46 disrupted mice with a strong expectation of causing sterility, but CD46 disrupted mice showed no visible damage to fertilizing ability in males or females (Inoue et al., 2003).

We then analyzed OBF13 monoclonal antibody that was raised against mouse sperm, binds only to acrosome-reacted sperm, and inhibits sperm-egg fusion in the mouse (Okabe et al., 1987). We recently identified the antigen by separation of crude extracts from mouse sperm by two-dimensional gel electrophoresis and subsequent immunoblotting with the monoclonal antibody. The identified spot was analyzed by liquid chromatography tandem mass spectrometry (LC-MS/MS). The antigen gene encodes an immunoglobulin superfamily (IgSF), type I membrane protein with an extracellular immunoglobulin domain that contains one putative glycosylation site. We termed the antigen "Izumo" after a Japanese Shinto shrine dedicated to marriage. We then produced an Izumo-disrupted mouse line. The Izumo-null males showed complete sterility despite normal mating behavior with normal vaginal plug formation. No offspring were fathered by these mice. When the sperm fertilizing ability was examined by in vitro fertilization system, many sperm were observed inside the perivitelline space indicating the fertilization was hampered at the sperm-egg fusion stage (Fig. 4B). However, when we performed intracytoplasmic sperm injection (ICSI) using Izumo ${ }^{-/}$sperm, they could activate the eggs, and the eggs were implanted normally and resulted in normal embryos. Therefore the deficiency of Izumo protein affects only to the sperm-egg fusion stage (Inoue et al., 2005).

\section{Relationship between the gene disruptions and their apparent phenotype}

We need to be careful about the "off target" effects of gene disruption. A targeted disruption of the myogenic basic-helixloop-helix gene Mrf4 is a good example. The phenotypes of three different Mrf4-disrupted mouse lines from three different laboratories with slightly different targeting vectors were very different, ranging from those showing complete viability of homozygotes to those displaying complete lethality. These three similar, but slightly different, targeting vectors had very different effects on expression of the adjacent Myf5 gene, which accounts for much of the phenotypic variation (Olson et al., 1996). Another good example of the potential pitfalls of gene disruption is the case of the disruption of the Prion gene (PrP). Five independent PrP knockout mouse lines have been reported with no phenotype (Bueler et al., 1992, Manson et al., 1994) and with cerebellar symptoms (Moore et al., 1999, Sakaguchi et al., 1996, Silverman et al., 2000). The discrepancy of the observation was associated with inter-gene splicing with neighboring Doppel gene in some of the targeting vectors (Flechsig et al., 2003, Rossi et al., 2001). To examine that the absence of Izumo directly caused the failure to fuse, we made a transgenic Izumo line driven by testis-specific calmegin promoter. The sterile phenotype was rescued with the transgenically-expressed Izumo on mouse sperm. Thus, we are certain that Izumo is the sperm factor shown to be essential for sperm-egg fusion.

\section{Generality of sperm-egg fusion factors}

In the sperm-zona binding event, ADAM3 holds the central position in the mouse, but the equivalent gene in human seems to be not producing functional protein (Frayne et al., 1999). We were curious to see if Izumo is species-specific. Therefore, Izumo ${ }^{-/}$ sperm were mixed with hamster eggs which are able to fuse with sperm from different species. As a result, it was shown that Izumo is essential for mouse sperm to fuse with hamster eggs. Likewise, fusion of human sperm to hamster eggs was inhibited by the addition of anti-human Izumo antibody. This may suggest that Izumo is involved in sperm-egg fusion in humans as well. However, as indicated throughout this review, the addition of antibody in the IVF condition often provides us with different views obtained from various gene-manipulated animals. Therefore, it is too early to conclude that Izumo is functional in humans. It will become clear if men with mutations in their Izumo gene are found to be infertile with a symptom of fusion disability. In any case, the first 
unambiguous fusion-related factors on sperm (Izumo) and on eggs (CD9) have been clarified. Again, the mice are available to the public through the Japanese animal distribution systems (indicated earlier). It is now a historic point in time, as we all are standing at the starting line of the elucidation of sperm-egg fusion.

\section{Conclusions}

Experiments using gene-manipulated animals are very powerful tools for judging the essentiality of concerned factors in fertilization. Of course, if a certain factor is judged as "not essential," it does not necessarily mean the factor is not functioning in vivo. However, the number of genes that are indispensable in fertilization is accumulating and their relationships with fertilization biology are emerging in the field of sperm-zona interaction. Gene disruption experiments are pursued in many research fields and the number of genes disrupted is increasing day by day. Thus, any genes that might affect reproduction will continue to be found even by researchers in different field. The day that we can draw a clear image of the sperm-egg fusion mechanism in molecular biology is definitely nearing.

\section{References}

ADHAM, I.M., NAYERNIA, K. and ENGEL, W. (1997). Spermatozoa lacking acrosin protein show delayed fertilization. Mol Reprod Dev 46: 370-6.

ASANO, M., FURUKAWA, K., KIDO, M., MATSUMOTO, S., UMESAKI, Y., KOCHIBE, N. and IWAKURA, Y. (1997). Growth retardation and early death of beta-1,4galactosyltransferase knockout mice with augmented proliferation and abnormal differentiation of epithelial cells. EMBO J16: 1850-7.

BABA, D., KASHIWABARA, S., HONDA, A., YAMAGATA, K., WU, Q., IKAWA, M., OKABE, M. and BABA, T. (2002). Mouse sperm lacking cell surface hyaluronidase ph-20 can pass through the layer of cumulus cells and fertilize the egg. $J$ Biol Chem 277: 30310-4.

BABA, T., AZUMA, S., KASHIWABARA, S. and TOYODA, Y. (1994). Sperm from mice carrying a targeted mutation of the acrosin gene can penetrate the oocyte zona pellucida and effect fertilization. J Biol Chem 269: 31854-31849.

BARROS, C. and YANAGIMACHI, R. (1971). Induction of zona reaction in golden hamster eggs by cortical granule material. Nature 233: 268-9.

BLOBEL, C., WOLFSBERG, T., TURCK, C., MYLES, D., PRIMAKOFF, P. and WHITE, J. (1992). A potential fusion peptide and an integrin ligand domain in a protein active in sperm-egg fusion. Nature 356: 248-252.

BOOKBINDER, L.H., CHENG, A. and BLEIL, J.D. (1995). Tissue- and speciesspecific expression of sp56, a mouse sperm fertilization protein. Science 269: 86-9.

BUELER, H., FISCHER, M., LANG, Y., BLUETHMANN, H., LIPP, H.P., DEARMOND, S.J., PRUSINER, S.B., AGUET, M. and WEISSMANN, C. (1992). Normal development and behaviour of mice lacking the neuronal cell-surface prp protein. Nature 356: 577-82.

CHAN, D.C., FASS, D., BERGER, J.M. and KIM, P.S. (1997). Core structure of gp41 from the hiv envelope glycoprotein. Cel/89: 263-73.

CHEN, H. and CHAN, D.C. (2005). Emerging functions of mammalian mitochondrial fusion and fission. Hum Mol Genet 14 Spec No. 2: R283-9.

CHEN, M.S., TUNG, K.S., COONROD, S.A., TAKAHASHI, Y., BIGLER, D., CHANG, A., YAMASHITA, Y., KINCADE, P.W., HERR, J.C. and WHITE, J.M. (1999). Role of the integrin-associated protein cd9 in binding between sperm adam 2 and the egg integrin alpha6beta1: Implications for murine fertilization. Proc Nat/ Acad Sci USA 96: 11830-5.

CHO, C., BUNCH, D.O., FAURE, J.E., GOULDING, E.H., EDDY, E.M., PRIMAKOFF, P. and MYLES, D.G. (1998). Fertilization defects in sperm from mice lacking fertilin beta. Science 281: 1857-9.

CROSS, N.L. and MEIZEL, S. (1989). Methods for evaluating the acrosomal status of mammalian sperm. Biol Reprod 41: 635-641.
DE JONGE, C. (2005). Biological basis for human capacitation. Hum Reprod Update 11: 205-14.

ENSSLIN, M.A. and SHUR, B.D. (2003). Identification of mouse sperm sed1, a bimotif egf repeat and discoidin-domain protein involved in sperm-egg binding. Cel/114: 405-17.

FLECHSIG, E., HEGYI, I., LEIMEROTH, R., ZUNIGA, A., ROSSI, D., COZZIO, A., SCHWARZ, P., RULICKE, T., GOTZ, J., AGUZZI, A. et al. (2003). Expression of truncated prp targeted to purkinje cells of prp knockout mice causes purkinje cell death and ataxia. EMBO J22: 3095-101.

FRAYNE, J., DIMSEY, E.A., JURY, J.A. and HALL, L. (1999). Transcripts encoding the sperm surface protein tmdc ii are non-functional in the human. Biochem $J$ 341 (Pt 3): 771-5.

FUKUDA, N., YOMOGIDA, K., OKABE, M. and TOUHARA, K. (2004). Functional characterization of a mouse testicular olfactory receptor and its role in chemosensing and in regulation of sperm motility. J Cell Sci117: 5835-45.

GMACHL, M. and KREIL, G. (1993). Bee venom hyaluronidase is homologous to a membrane protein of mammalian sperm. Proc Nat/ Acad Sci USA 90: 356973.

GUR, Y. and BREITBART, H. (2006). Mammalian sperm translate nuclear-encoded proteins by mitochondrial-type ribosomes. Genes Dev20: 411-6.

HAGAMAN, J.R., MOYER, J.S., BACHMAN, E.S., SIBONY, M., MAGYAR, P.L., WELCH, J.E., SMITHIES, O., KREGE, J.H. and O'BRIEN, D.A. (1998). Angiotensin-converting enzyme and male fertility. Proc Nat/ Acad Sci USA 95: 25527.

HARDY, D.M. and GARBERS, D.L. (1995). A sperm membrane protein that binds in a species-specific manner to the egg extracellular matrix is homologous to von willebrand factor. $J$ Biol Chem 270: 26025-8.

HONDA, A., YAMAGATA, K., SUGIURA, S., WATANABE, K. and BABA, T. (2002). A mouse serine protease tesp5 is selectively included into lipid rafts of sperm membrane presumably as a glycosylphosphatidylinositol-anchored protein. $J$ Biol Chem 277: 16976-84.

IKAWA, M., NAKANISHI, T., YAMADA, S., WADA, I., KOMINAMI, K., TANAKA, H., NOZAKI, M., NISHIMUNE, Y. and OKABE, M. (2001). Calmegin is required for fertilin alpha/beta heterodimerization and sperm fertility. Dev Bio/240: 254-61.

IKAWA, M., WADA, I., KOMINAMI, K., WATANABE, D., TOSHIMORI, K., NISHIMUNE, Y. and OKABE, M. (1997). The putative chaperone calmegin is required for sperm fertility. Nature 387: 607-611.

INOUE, N., IKAWA, M., ISOTANI, A. and OKABE, M. (2005). The immunoglobulin superfamily protein izumo is required for sperm to fuse with eggs. Nature 434 : 234-8.

INOUE, N., IKAWA, M., NAKANISHI, T., MATSUMOTO, M., NOMURA, M., SEYA, T. and OKABE, M. (2003). Disruption of mouse cd46 causes an accelerated spontaneous acrosome reaction in sperm. Mol Cel/ Bio/23: 2614-22.

ISOTANI, A., NAKANISHI, T., KOBAYASHI, S., LEE, J., CHUMA, S., NAKATSUJI, N., ISHINO, F. and OKABE, M. (2005). Genomic imprinting of $x x$ spermatogonia and $\mathrm{xx}$ oocytes recovered from $\mathrm{xx}<->\mathrm{xy}$ chimeric testes. Proc Nat/ Acad Sci USA 102: 4039-44.

JANSEN, S., EKHLASI-HUNDRIESER, M. and TOPFER-PETERSEN, E. (2001). Sperm adhesion molecules: Structure and function. Cel/s Tissues Organs 168: 82-92.

KAJI, K., ODA, S., SHIKANO, T., OHNUKI, T., UEMATSU, Y., SAKAGAMI, J., TADA, N., MIYAZAKI, S. and KUDO, A. (2000). The gamete fusion process is defective in eggs of cd9-deficient mice. Nat Genet 24: 279-82.

KIM, E., BABA, D., KIMURA, M., YAMASHITA, M., KASHIWABARA, S. and BABA, T. (2005). Identification of a hyaluronidase, hyal5, involved in penetration of mouse sperm through cumulus mass. Proc Nat/ Acad Sci USA 102: 18028-33.

KIM, E., NISHIMURA, H. and BABA, T. (2003). Differential localization of adam1a and adam $1 \mathrm{~b}$ in the endoplasmic reticulum of testicular germ cells and on the surface of epididymal sperm. Biochem Biophys Res Commun 304: 313-9.

KIM, E., YAMASHITA, M., NAKANISHI, T., PARK, K.E., KIMURA, M., KASHIWABARA, S. and BABA, T. (2006). Mouse sperm lacking adam1b/ adam2 fertilin can fuse with the egg plasma membrane and effect fertilization. $J$ Biol Chem 281: 5634-9.

KIM, K.S. and GERTON, G.L. (2003). Differential release of soluble and matrix components: Evidence for intermediate states of secretion during spontaneous acrosomal exocytosis in mouse sperm. Dev Bio/264: 141-52. 
KIMCHI, T., XU, J. and DULAC, C. (2007). A functional circuit underlying male sexual behaviour in the female mouse brain. Nature 448: 1009-14.

LARSON, J.L. and MILLER, D.J. (1999). Simple histochemical stain for acrosomes on sperm from several species. Mol Reprod Dev 52: 445-9.

LE NAOUR, F., RUBINSTEIN, E., JASMIN, C., PRENANT, M. and BOUCHEIX, C. (2000). Severely reduced female fertility in cd9-deficient mice. Science 287: 319-21.

LEA, I.A., SIVASHANMUGAM, P. and O'RAND, M.G. (2001). Zonadhesin: Characterization, localization, and zona pellucida binding. Biology of Reproduction 65: 1691-1700.

LIN, Y.N., ROY, A., YAN, W., BURNS, K.H. and MATZUK, M.M. (2007). Loss of zona pellucida binding proteins in the acrosomal matrix disrupts acrosome biogenesis and sperm morphogenesis. Mol Cell Bio/27: 6794-805.

LU, M., BLACKLOW, S.C. and KIM, P.S. (1995). A trimeric structural domain of the hiv-1 transmembrane glycoprotein. Nat Struct Bio/2: 1075-82.

LU, Q. and SHUR, B.D. (1997). Sperm from beta 1,4-galactosyltransferase-null mice are refractory to zp3-induced acrosome reactions and penetrate the zona pellucida poorly. Development 124: 4121-31.

MANSON, J.C., CLARKE, A.R., HOOPER, M.L., AITCHISON, L., MCCONNELL, I. and HOPE, J. (1994). 129/ola mice carrying a null mutation in prp that abolishes mrna production are developmentally normal. Mol Neurobio/8: 121-7.

MARGULIS, L. and SAGAN, D. (1986). Origins of sex. Three billion years of genetic recombination. Yale University Press, New Haven and London.

MILLER, B.J., GEORGES-LABOUESSE, E., PRIMAKOFF, P. and MYLES, D.G. (2000). Normal fertilization occurs with eggs lacking the integrin alpha6beta1 and is cd9-dependent. J Cell Bio/149: 1289-96.

MIYADO, K., YAMADA, G., YAMADA, S., HASUWA, H., NAKAMURA, Y., RYU, F., SUZUKI, K., KOSAI, K., INOUE, K., OGURA, A. et al. (2000). Requirement of cd9 on the egg plasma membrane for fertilization. Science 287: 321-4.

MOORE, R.C., LEE, I.Y., SILVERMAN, G.L., HARRISON, P.M., STROME, R., HEINRICH, C., KARUNARATNE, A., PASTERNAK, S.H., CHISHTI, M.A., LIANG, Y. et al. (1999). Ataxia in prion protein (prp)-deficient mice is associated with upregulation of the novel prp-like protein doppel. JMo/Bio/292: 797-817.

NAKANISHI, T., IKAWA, M., YAMADA, S., PARVINEN, M., BABA, T., NISHIMUNE, $Y$. and OKABE, M. (1999). Real-time observation of acrosomal dispersal from mouse sperm using gfp as a marker protein. FEBS Lett 449: 277-83.

NAKANISHI, T., ISOTANI, A., YAMAGUCHI, R., IKAWA, M., BABA, T., SUAREZ, S.S. and OKABE, M. (2004). Selective passage through the uterotubal junction of sperm from a mixed population produced by chimeras of calmegin-knockout and wild-type male mice. Biol Reprod71: 959-65.

NISHIMURA, H., CHO, C., BRANCIFORTE, D.R., MYLES, D.G. and PRIMAKOFF, $P$. (2001). Analysis of loss of adhesive function in sperm lacking cyritestin or fertilin beta. Dev Bio/233: 204-13.

NISHIMURA, H., KIM, E., FUJIMORI, T., KASHIWABARA, S., KUROIWA, A., MATSUDA, Y. and BABA, T. (2002). The adam1a and adam1b genes, instead of the adam1 (fertilin alpha) gene, are localized on mouse chromosome 5 . Gene 291: $67-76$

NISHIMURA, H., KIM, E., NAKANISHI, T. and BABA, T. (2004). Possible function of the adam $1 \mathrm{a} /$ adam 2 fertilin complex in the appearance of adam 3 on the sperm surface. J Biol Chem 279: 34957-62.

OKABE, M., ADACHI, T., TAKADA, K., ODA, H., YAGASAKI, M., KOHAMA, Y. and MIMURA, T. (1987). Capacitation-related changes in antigen distribution on mouse sperm heads and its relation to fertilization rate in vitro. $J$ Reprod Immuno/11: 91-100.

OKABE, M., NAGIRA, M., KAWAI, Y., MATZNO, S., MIMURA, T. and MAYUMI, T. (1990). A human sperm antigen possibly involved in binding and/or fusion with zona-free hamster eggs. Fertil Steril54: 1121-6.

OLSON, E.N., ARNOLD, H.H., RIGBY, P.W. and WOLD, B.J. (1996). Know your neighbors: Three phenotypes in null mutants of the myogenic bhlh gene mrf4.
Cel/85: 1-4.

PRIMAKOFF, P., LATHROP, W., WOOLMAN, L., COWAN, A. and MYLES, D. (1988). Fully effective contraception in male and female guinea pigs immunized with the sperm protein ph-20. Nature 335: 543-6.

ROSSI, D., COZZIO, A., FLECHSIG, E., KLEIN, M.A., RULICKE, T., AGUZZI, A. and WEISSMANN, C. (2001). Onset of ataxia and purkinje cell loss in prp null mice inversely correlated with dpl level in brain. EMBO J20: 694-702.

SAKAGUCHI, S., KATAMINE, S., NISHIDA, N., MORIUCHI, R., SHIGEMATSU, K., SUGIMOTO, T., NAKATANI, A., KATAOKA, Y., HOUTANI, T., SHIRABE, S. et al. (1996). Loss of cerebellar purkinje cells in aged mice homozygous for a disrupted prp gene. Nature 380: 528-31.

SALING, P.M. and STOREY, B.T. (1979). Mouse gamete interactions during fertilization in vitro. Chlortetracycline as a fluorescent probe for the mouse sperm acrosome reaction. J Cel/ Bio/83: 544-55.

SHAMSADIN, R., ADHAM, I.M., NAYERNIA, K., HEINLEIN, U.A., OBERWINKLER, H. and ENGEL, W. (1999). Male mice deficient for germ-cell cyritestin are infertile. Biol Reprod 61: 1445-51.

SILVERMAN, G.L., QIN, K., MOORE, R.C., YANG, Y., MASTRANGELO, P., TREMBLAY, P., PRUSINER, S.B., COHEN, F.E. and WESTAWAY, D. (2000). Doppel is an n-glycosylated, glycosylphosphatidylinositol-anchored protein. Expression in testis and ectopic production in the brains of $\operatorname{prnp}(0 / 0)$ mice predisposed to purkinje cell loss. J Biol Chem 275: 26834-41.

SPEHR, M., GISSELMANN, G., POPLAWSKI, A., RIFFELL, J.A., WETZEL, C.H., ZIMMER, R.K. and HATT, H. (2003). Identification of a testicular odorant receptor mediating human sperm chemotaxis. Science 299: 2054-8.

STEIN, K.K., GO, J.C., PRIMAKOFF, P. and MYLES, D.G. (2005). Defects in secretory pathway trafficking during sperm development in adam2 knockout mice. Biol Reprod 73: 1032-8.

TALBOT, P., GEISKE, C. and KNOLL, M. (1999). Oocyte pickup by the mammalian oviduct. Mol Biol Cel/10: 5-8.

TOSHIMORI, K., SAXENA, D.K., TANII, I. and YOSHINAGA, K. (1998). An mn9 antigenic molecule, equatorin, is required for successful sperm-oocyte fusion in mice. Biol Reprod 59: 22-9.

TSUJIMURA, A., SHIDA, K., KITAMURA, M., NOMURA, M., TAKEDA, J., TANAKA, H., MATSUMOTO, M., MATSUMIYA, K., OKUYAMA, A., NISHIMUNE, Y. et al. (1998). Molecular cloning of a murine homologue of membrane cofactor protein (cd46): Preferential expression in testicular germ cells. Biochem $J 330$ (Pt 1): 163-8.

WASSARMAN, P.M. (1992). Mouse gamete adhesion molecules. Biol Reprod 46: 186-91.

WEISSENHORN, W., DESSEN, A., HARRISON, S.C., SKEHEL, J.J. and WILEY, D.C. (1997). Atomic structure of the ectodomain from hiv-1 gp41. Nature 387: 426-30.

YAGI, M., MIYAMOTO, T., SAWATANI, Y., IWAMOTO, K., HOSOGANE, N., FUJITA, N., MORITA, K., NINOMIYA, K., SUZUKI, T., MIYAMOTO, K. et al. (2005). Dc-stamp is essential for cell-cell fusion in osteoclasts and foreign body giant cells. J Exp Med202: 345-51.

YAMAGUCHI, R., YAMAGATA, K., IKAWA, M., MOSS, S.B. and OKABE, M. (2006). Aberrant distribution of adam3 in sperm from both angiotensin-converting enzyme (ace)- and calmegin (clgn)-deficient mice. Biol Reprod 75: 760-6.

YANAGIMACHI, R. (1994). Mammalian fertilization. In The physiology of reproduction, (ed. KNOBIL, E. and NEILL, J. D.). Raven Press, Ltd., New York, pp.189317.

YOSHIDA, M., MURATA, M., INABA, K. and MORISAWA, M. (2002). A chemoattractant for ascidian spermatozoa is a sulfated steroid. Proc Nat/ Acad Sci USA 99: 14831-6.

YUDIN, A.I., VANDEVOORT, C.A., LI, M.W. and OVERSTREET, J.W. (1999). Ph20 but not acrosin is involved in sperm penetration of the macaque zona pellucida. Mol Reprod Dev 53: 350-62. 


\section{Related, previously published Int. J. Dev. Biol. articles}

See our recent Special Issue Developmental Biology in Poland edited by Tarkowski, Maleszewski and Kloc at: http://www.ijdb.ehu.es/web/contents.php?vol=52\&issue=2-3

See our recent Special Issue Ear Development edited by Fernando Giraldez and Bernd Fritzsch at: http://www.ijdb.ehu.es/web/contents.php?vol=51\&issue=6-7

Defective calcium release during in vitro fertilization of maturing oocytes of LT/Sv mice Karolina Archacka, Anna Ajduk, Pawel Pomorski, Katarzyna Szczepanska, Marek Maleszewski and Maria A. Ciemerych Int. J. Dev. Biol. (2008) 52: doi: 10.1387/ijdb.072397ka

Ca2+-independent protein kinase $\mathbf{C}$ signalling in mouse eggs during the early phases of fertilization. Carla Tatone, Simona Delle Monache, Antonella Francione, Luisa Gioia, Barbara Barboni and Rosella Colonna Int. J. Dev. Biol. (2003) 47: 327-333

Distinct mechanisms underlie sperm-induced and protease-induced oolemma block to sperm penetration. Sebastian Komorowski, Katarzyna Szczepanska and Marek Maleszewski Int. J. Dev. Biol. (2003) 47: 65-69

Association of egg zona pellucida glycoprotein mZP3 with sperm protein sp56 during fertilization in mice. $\mathrm{N}$ Cohen and $\mathrm{P} M$ Wassarman

Int. J. Dev. Biol. (2001) 45: 569-576

Fertilization triggers activation of Fyn kinase in the zebrafish egg.

W Wu and W H Kinsey

Int. J. Dev. Biol. (2000) 44: 837-841

Sperm-egg interaction at fertilization: glycans as recognition signals. F Rosati, A Capone, C D Giovampaola, C Brettoni and R Focarelli Int. J. Dev. Biol. (2000) 44: 609-618

Requirement of protamine for maintaining nuclear condensation of medaka (Oryzias latipes) spermatozoa shed into water but not for promoting nuclear condensation during spermatogenesis.

Y Shimizu, K Mita, M Tamura, K Onitake and M Yamashita

Int. J. Dev. Biol. (2000) 44: 195-199

Analysis of polysulfate-binding domains in porcine proacrosin, a putative zona adhesion protein from mammalian spermatozoa.

$S$ Jansen, $M$ Quigley, W Reik and R Jones

Int. J. Dev. Biol. (1995) 39: 501-510

Egg-jelly signal molecules for triggering the acrosome reaction in starfish spermatozoa.

M Hoshi, T Nishigaki, A Ushiyama, T Okinaga, K Chiba and M Matsumoto

Int. J. Dev. Biol. (1994) 38: 167-174

2006 ISI **Impact Factor $=3.577^{\star *}$

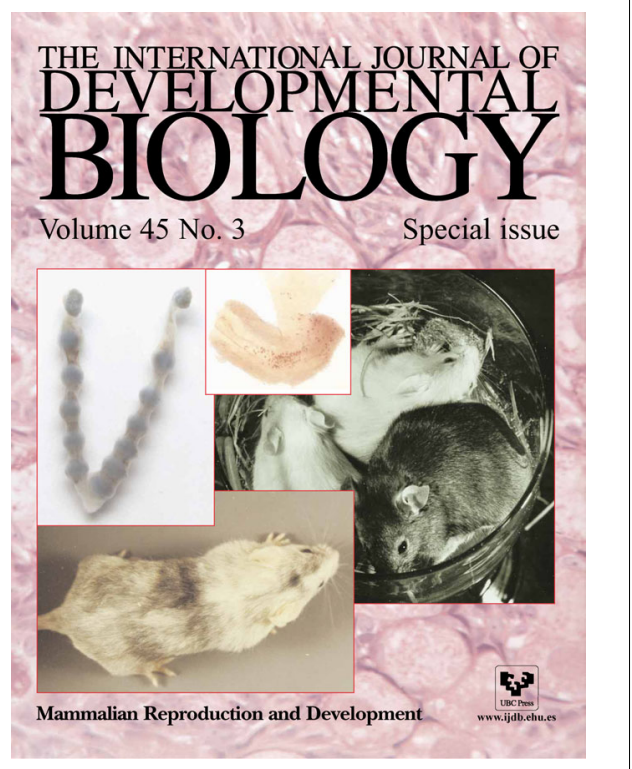

